\title{
Pharyngeal Cancer TNM Finding v7
}

National Cancer Institute

\section{Source}

National Cancer Institute. Pharyngeal Cancer TNM Finding v7. NCI Thesaurus. Code C88963.

A finding about one or more characteristics of pharyng eal cancer, following the rules of the TNM AJCC v7 classification system. Nonepithelial tumors such as those of lymphoid tissue, soft tissue, bone, and cartilage are not included in this classification. (from AJCC 7th Ed.) 